\title{
PENGARUH RELATIONSHIP MARKETING, CUSTOMER VALUE, DAN TRUST TERHADAP LOYALITAS PELANGGAN PADA PT. ASURANSI JIWASRAYA CABANG KOTA MALANG
}

\author{
Anggrahita Satriyo Wiwoho \\ Department of Management FEB UMM \\ E-mail : anggaselendroe@gmail.com
}

\begin{abstract}
The purpose of this study was to determined the effect of relationship marketing, costumer value, and trust on the customer's loyalty at PT.Jiwasraya Insurance branch of Malang. This study used multiple linear regression analysis and tested on 100 Respodents that have been determined by used purposive sampling technique as a method, and used questionnaires for data collection. The result of this study were concluded that variables such as:1) Relationship marketing significally influenced the customer's loyalty of PT Jiwasraya Insurance branch of Malang. 2) Customer value significally influenced the customer's loyalty of PT Jiwasraya Insurance branch of Malang. 3) Trust was significally influenced the customer's loyalty of PT Jiwasraya Insurance branch of malang.
\end{abstract}

Keywords: relationship marketing, customer value, trust, customer loyalty.

\section{PENDAHULUAN}

$\begin{array}{ccr}\text { Suatu bisnis memiliki tujuan } \\ \text { untuk } & \text { menciptakan dan }\end{array}$ mempertahankan bisnis, namun setiap perusahaan lebih mengutamakan penciptaan pelanggan baru dari pada mempertahankan pelanggan yang sudah ada (Ferinadewi, 2008). Tujuan dari mempertahankan pelanggan adalah membentuk loyalitas pelanggan.

Pelanggan yang loyal akan memberikan keuntungan bagi sebuah perusahaan dan meningkatkan profabilitas perusahaan. Seorang pelanggan dikatakan loyal atau setia apabila pelanggan tersebut menunjukkan perilaku pembelian secara teratur atau mewajibkan konsumen membeli paling sedikit dua kali selang waktu tertentu
(Griffin, 2010). Loyalitas pelanggan terbentuk dari penilaian pelanggan terhadap kualitas produk atau jasa yang di terimanya berdasarkan harapan yang telah terkonsep dalam pikirannya. Ada beberapa variabel yang mempengaruhi pelanggan menjadi loyal terhadap sebuah perusahaan yaitu relationship marketing (Pasaribu,2017), customer value (Rahi,2016), ataupun trust (Fihartini,2010).

Salah satu pendekatan pemasar saat ini yang digunakan perusahaan adalah relationship marketing, dengan prinsip pemasar yang menekankan pada hubungan baik dalam jangka panjang dengan pelanggan, pemasok, dan distributor. Selain itu juga dengan customer value, yaitu selisih antara total nilai 
tambah yang diperoleh konsumen dibandingkan dengan total biaya yang dikeluarkan. Pada penelitian terdahulu oleh Rahi (2016) menjelaskan bahwa nilai pelanggan berpengaruh positif dan signifikan terhadap loyalitas pelanggan. Sehingga terbentuknya pelanggan yang loyal dan akan melakukan pembelian ulang terhadap produk jasa tersebut. Setelah customer value, variabel berikutnya yaitu kepercayaan atau trust.

Kepercayaan merupakan faktor paling krusial dalam setiap relasi, sekaligus berpengaruh pada loyalitas (Sheth dan Mittal, dalam Tjiptono, 2014). Tingkat kepercayaan nasabah merupakan faktor yang membangun loyalitas nasabah asuransi untuk tetap bertahan pada suatu perusahaan asuransi.

Salah satu perusahaan asuransi yang terus bertahan dalam persaingan jasa asuransi di Indonesia adalah PT. Asuransi Jiwasraya. Hal tersebut ditunjukkan dengan beberapa prestasi dari PT. Asuransi Jiwasraya. Pada tahun 2018 PT. Asuransi Jiwasraya mengalami kenaikan dan menempati posisi kedua pada TOP Brand Indonesia. Hal ini menunjukkan bahwa pelanggan masih memiliki tingkat kepercayaan yang tinggi terhadap perusahaan asuransi Jiwasraya. PT. Asuransi Jiwasraya juga meraih penghargaan BUMN performance excellence dengan level band good performance dan dengan raihan skor sebesar 502,25, yang menunjukkan bahwa pelayanan yang diberikan PT. Asuransi Jiwasraya baik.

Terlihat dari fenomena tersebut asuransi Jiwasraya merupakan penyedia jasa asuransi jiwa yang tertua sehingga tingkat pengalaman yang didapat oleh perusahaan ini sangat lah banyak. Pelayanan yang diberikan selalu melakukan inovasi terhadap konsumen, dan juga pada lini produk - produk asuransi yang ditawarkan tidak menyasar pada jiwa saja melainkan pada segi kesehatan, pendidikan, dan jaminan hari tua. Keadaan tersebut menunjukkan bahwa konsumen akan menjadi loyal terhadap perusahaan asuransi jiwa di PT. Asuransi Jiwasraya. Berdasarkan fenomena tersebut maka tujuan dari penelitian ini adalah luntuk mengetahui pengaruh dari relationship marketing, customer value, dan trust terhadap loyalitas pelanggan, pada PT. Asuransi Jiwasraya cabang kota Malang.

\section{TINJAUAN PUSTAKA}

Menurut Lovelock dan Jochen (2011) loyalitas pelanggan adalah pelanggan yang bersedia untuk terus berlangganan pada sebuah perusahaan dalam jangka panjang, dengan membeli atau menggunakan barang dan jasanya secara berulangulang dan lebih baik lagi secara ekslusif dan sukarela merekomendasikan kepada orang lain. Loyalitas merupakan suatu faktor penting bagi suatu perusahaan untuk dapat terus bertahan dalam persaingan bisnis yang tercermin dari antusias pelanggan atas produk atau jasa. Terdapat empat jenis loyalitas yang muncul bila keterikatan rendah dan tinggi diklasifikasi-silang dengan pola pembelian ulang, yang rendah dan tinggi ( Griffin, 2010) antara lain: tanpa loyalitas, loyalitas yang lemah (inertia loyality), loyalitas tersembunyi (laten loyality), loyalitas premium (premium loyalty). 
Relationship marketing adalah proses membangun hubungan jangka panjang yang saling memuaskan dengan pihak-pihak yang memiliki kepentingan utama, pelanggan, pemasok, distributor, dalam rangka mendapatkan serta memepertahankan preferensi dan kelangsungan bisnis jangka panjang mereka (Kotler, 2002). Relationship marketing merupakan upaya pengenalan kepada setiap pelanggan secara lebih dekat, menciptakan komunikasi dua arah dengan konsumen, dan mengelola hubungan yang saling antara pelanggan dan konsumen.

Menurut Kotler dan Amstrong (2010) terdapat tiga manfaat relationship marketing yaitu manfaat ekonomi, sosial, dan ikatan struktural. Penelitian terdahulu yang dilakukan oleh Pasaribu (2017) telah membuktikan secara empiris bahwa relationship marketing dapat meningkatkan loyalitas konsumen.

Menurut Cannon et al. (2008) nilai pelanggan adalah perbedaan anatara manfaat yang dilihat seorang pelanggan dari suatu penawaran pasar serta biaya untuk mendapatkan manfaat tersebut. Nilai pelanggan atau customer perceived value yaitu persepsi pelanggan terhadap nilai dimana perusahaan harus mempertimbangkan nilai dalam mengembangkan produk dan jasanya sehingga sesuai dengan apa yang diharapkan pelanggan (Vanessa, 2007). Penelitian terdahulu yang dilakukan oleh Rahi (2016) telah membuktikan secara empiris bahwa customer value dapat meningkatkan loyalitas konsumen.

Menurut Barnes (2011) kepercayaan adalah keyakinan bahwa seseorang akan menemukan apa yang diinginkan pada mitra kerjanya. Konsumen yang percaya terhadap suatu perusahaan maka konsumen tersebut akan memiliki keyakinan akan keahlian perusahaan tersebut untuk dapat melayani secara baik, memuaskan dan dapat diandalkan, juga merupakan suatu keyakinan bahwa maksud dan motivasi perusahaan akan membawa keuntungan bagi konsumen dan tidak akan berpengaruh negatif dan merugikan konsumen (Fihartini, 2010). Berdasarkan pemaparan fenomena dan kajian pustaka diatas maka kerangka hipotesis penelitian yang diteliti pada penelitian ini adalah sebagai berikut:

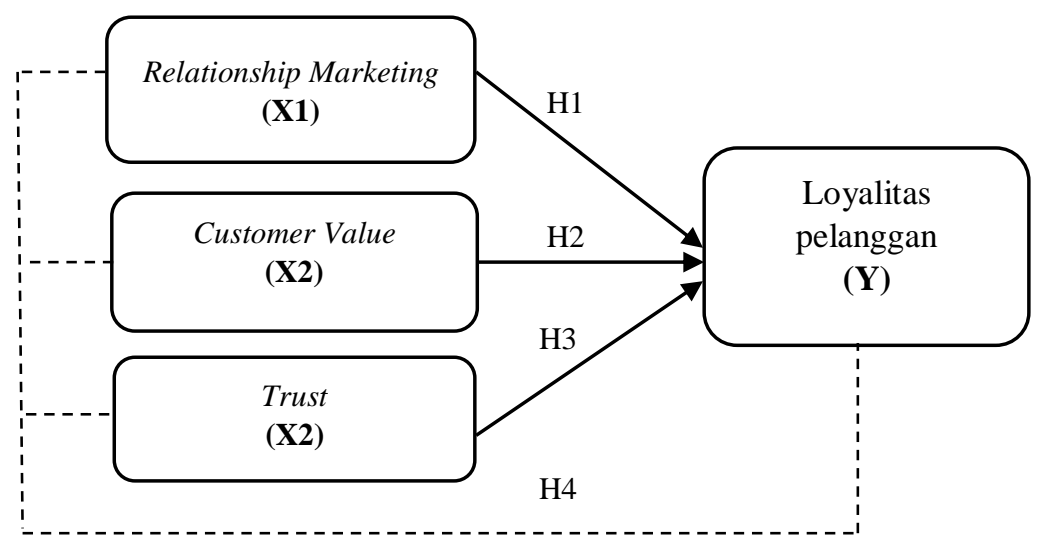

Gambar 1. Kerangka Hipotesis Penelitian 
Hipotesis yang diajukan dalam penelitian ini yaitu, $\mathrm{H} 1$, relationship marketing berpengaruh terhadap loyalitas pelanggan. $\mathrm{H} 2$, customer value berpengaruh terhadap loyalitas pelanggan. $\mathrm{H} 3$, trust berpengaruh terhadap loyalitas pelanggan. $\mathrm{H} 4$, variabel yang memberikan kontribusi terbesar pengaruhnya terhadap loyalitas pelanggan pada PT. Asuransi Jiwasraya cabang kota Malang adalah variabel relationship marketing.

\section{METODE PENELITIAN}

Penelitian ini merupakan penelitian kuantitatif dengan metode survey menggunakan kuesioner. Penelitian ini dilakukan di Asuransi Jiwasraya Cabang Kota Malang yang berlokasi di jalan Brigjend Slamet Riyadi No.18, Malang, Jawa Timur. Populasi dalam penelitian ini adalah seluruh nasabah asuransi Jiwasraya cabang kota Malang. Untuk memperoleh sampel penelitian ini menggunakan metode non probability sampling dengan teknik purposive sampling. Jumlah sampel pada penelitian ini adalah 100 responden.

Penelitian ini menggunakan data primer yang diperoleh dari jawaban kuesioner yang disebarkan kepada responden. Skala likert lima tingkat digunakan untuk mengukur jawaban responden terhadap masing -masing item pernyataan dalam kuesioner. Data yang telah terkumpul selanjutnya akan dilakukan analisis deskriptif dan analisis statistik inferensial menggunakan bantuan software SPSS.

Definisi operasional variabelvariabel dalam penelitian ini akan dijelaskan sebagai berikut.
Relationship marketing adalah proses menciptakan, mempertahankan dan meningkatkan hubungan yang kuat, bernilai tinggi dengan pelanggan (Kotler,2002). Dalam mengukur relationship marketing indikator yang digunakan adalah bonding, empathy, dan reciprocity (Tandjung, 2004).

Customer value adalah semua manfaat dan pengorbanan, dimana pelanggan akan membandingkan perolehan dari manfaat dan pengorbanan yang dilakukan (Kotler, 2005). Indikator yang digunakan untuk mengukur customer value adalah emotional, social, quality/performance value, dan price/value for money (Sweeney \& Soutar dalam Tjiptono, 2014).

Kepercayaan (trust) adalah suatu keyakinan kepada pihak lain yang menjadi mitra bisnis, bahwa mitra bisnis tersebut akan menjalankan segala kewajibannya dengan baik sesuai yang diharapkan (Barnes, 2011). Indikator untuk mengukur trust antara lain kepercayaan pelanggan pada reputasi perusahaan, keamanan dan kenyamanan dalam menggunakan produk, serta keyakinan pelanggan akan manfaat dan kualitas produk yang ditawarkan perusahaan (Ramadania, 2002).

Loyalitas pelanggan adalah komitmen pelanggan bertahan secara mendalam untuk berlangganan kembali atau melakukan pembelian ulang produk atau jasa(Tjiptono, 2014). Indikator yang digunakan untuk mengukur loyalitas antara lain kesetiaan terhadap pembelian produk (repeat purchase), ketahanan terhadap pengaruh yang negatif mengenai perusahaan (retention), serta mereferensikan secara total 
esistensi perusahaan (referalls) (Kotler dan Keller, 2006).

\section{HASIL PENELITIAN DAN PEMBAHASAN}

Pada penelitian ini instrumen pengukuran variabel variabel dalam penelitian akan diuji terlebih dahulu validitas dan reliabilitasnya. Tabel 1 dan Tabel 2 menunjukkan hasil dari uji validitas dan reliabilitas instrumen penelitian yang menggunakan software SPSS. Pada Tabel 1. Tampak bahwa seluruh item-item pernyataan dari kuesioner telah valid karena, masing-masing item mempunyai nilai $r$ hitung $>$ dari $\mathrm{r}$ tabel. Sehingga item-item tersebut dianggap layak dan tepat untuk mengukur variabel-variabel dalam penelitian ini. Hasil uji reliabilitas pada Tabel 2. menunjukkan bahwa nilai cronbach Alpha masing-masing variabel lebih dari 0.6. Hal tersebut menunjukkan kuesioner pada penelitian ini dinyatakan reliabel atau menghasilkan data yang relatif konsisten ketika digunakan berulangulang terhadap subjek dan kondisi yang sama.

Tabel 1. Hasil Uji Validitas

\begin{tabular}{cccc}
\hline Item & $\mathrm{r}$ hitung & $\mathrm{r}$ tabel & Ket \\
\hline Relationship marketing $\left(X_{1}\right)$ & & & \\
$\mathrm{X}_{1 \cdot 1 \cdot 1}$ & 0,867 & 0.196 & Valid \\
$\mathrm{X}_{1 \cdot 1 \cdot 2}$ & 0,642 & 0.196 & Valid \\
$\mathrm{X}_{1 \cdot 2 \cdot 1}$ & 0,575 & 0.196 & Valid \\
$\mathrm{X}_{1 \cdot 2 \cdot 2}$ & 0,726 & 0.196 & Valid \\
$\mathrm{X}_{1 \cdot 3 \cdot 1}$ & 0,836 & 0.196 & Valid \\
$\mathrm{X}_{1 \cdot 3 \cdot 2}$ & 0,731 & 0.196 & Valid \\
Customer value $\left(X_{2}\right)$ & & & \\
$\mathrm{X}_{2 \cdot 1 \cdot 1}$ & 0,702 & 0.196 & Valid \\
$\mathrm{X}_{2 \cdot 1 \cdot 2}$ & 0,828 & 0.196 & Valid \\
$\mathrm{X}_{2 \cdot 2 \cdot 1}$ & 0,779 & 0.196 & Valid \\
$\mathrm{X}_{2 \cdot 2 \cdot 2}$ & 0,847 & 0.196 & Valid \\
$\mathrm{X}_{2 \cdot 3 \cdot 1}$ & 0,759 & 0.196 & Valid \\
$\mathrm{X}_{2 \cdot 3 \cdot 2}$ & 0,806 & 0.196 & Valid \\
$\mathrm{X}_{2 \cdot 4 \cdot 1}$ & 0,645 & 0.196 & Valid \\
$\mathrm{X}_{2 \cdot 4 \cdot 2}$ & 0,625 & 0.196 & Valid \\
Trust $\left(X_{3}\right)$ & & & \\
$\mathrm{X}_{3 \cdot 1 \cdot 1}$ & 0,916 & 0.196 & Valid \\
$\mathrm{X}_{3 \cdot 2 \cdot 1}$ & 0,853 & 0.196 & Valid \\
$\mathrm{X}_{3 \cdot 3 \cdot 1}$ & 0,869 & 0.196 & Valid \\
Loyalitas Pelanggan $(\mathrm{Y})$ & & & \\
$\mathrm{Y}_{\cdot 1 \cdot 1}$ & 0,943 & 0.196 & Valid \\
$\mathrm{Y}_{\cdot 2 \cdot 1}$ & 0,751 & 0.196 & Valid \\
$\mathrm{Y}_{\cdot 3 \cdot 1}$ & 0,941 & 0.196 & Valid \\
\hline
\end{tabular}

Tabel 2. Hasil Uji Reliabilitas

\begin{tabular}{ccc}
\hline Variabel & Cronbach Alpha & Keterangan \\
\hline Relationship marketing $\left(x_{1}\right)$ & 0,831 & Reliabel \\
Customer value $\left(x_{2}\right)$ & 0,885 & Reliabel \\
Trust $\left(x_{3}\right)$ & 0,853 & Reliabel \\
Loyalitas pelanggan $(\mathrm{Y})$ & 0,857 & Reliabel \\
\hline
\end{tabular}

Tabel 3. menunjukkan hasil analisis regresi liear berganda untuk 
mengetahui hubungan antara variabel bebas dengan variabel terikat dalam penelitian ini. Analisis tersebut dilakukan dengan software SPSS. Berikut adalah hasil analisis regresi linier berganda:

Tabel 3. Hasil Analisis Regresi Linear Berganda

\begin{tabular}{lccc}
\hline \multicolumn{1}{c}{ Variabel } & Standardized Coefficients & T & Sig. \\
\hline Relationship Marketing (X1) & 0,402 & 3,904 & 0,000 \\
Customer Value (X2) & 0,282 & 2,614 & 0,010 \\
Trust (X3) & 0,209 & 2,472 & 0,015 \\
\hline
\end{tabular}

Berdasarkan perhitungan pada Tabel 3 di atas, maka dapat dinotasikan dengan persamaan regresi sebagai berikut : $\mathrm{Y}=1,035+0,224 \mathrm{X}_{1}+$ $0,103 \mathrm{X}_{2}+0,201 \mathrm{X}_{3}$

Dari persamaan di atas dapat diinterpretasikan sebagai berikut. Nilai konstanta 1,035, menunjukkan bahwa apabila tidak ada relationship marketing, customer value, dan trust maka pelanggan pada PT. Asuransi Jiwasraya cabang kota Malang akan tetap loyal.

Nilai b1 sebesar 0,224, menunjukkan bahwa semakin baik relationship marketing maka loyalitas pelanggan pada PT. Asuransi Jiwasraya cabang kota Malang akan semakin meningkat. Nilai b2 sebesar 0,103 menunjukkan semakin tinggi customer value maka loyalitas pelanggan pada PT. Asuransi Jiwasraya cabang kota Malang akan semakin meningkat.

Nilai b3 sebesar 0,201, bahwa apabila semakin tinggi trust maka loyalitas pelanggan pada PT. Asuransi Jiwasraya cabang kota Malang akan semakin meningkat. Berdasarkan Tabel 2. diatas, nilai tertinggi di peroleh dari variabel relationship marketing sebesar 0,224, kemudian diikuti variabel trust sebesar 0,201, dan nilai terendah diperoleh dari variabel customer value yaitu sebesar 0,103. Dengan demikian menurut keterangan diatas koefisien regresi yang paling tinggi adalah 0,224, menunjukkan variabel yang paling dominan adalah relationship marketing.

Tabel 4. Hasil Uji t

\begin{tabular}{lcccc}
\hline \multicolumn{1}{c}{ Variabel } & $\mathrm{T}_{\text {hitung }}$ & $\mathrm{T}_{\text {tabel }}$ & Sig & Keterangan \\
\hline Relationship Marketing (X1) & 3,904 & 1,988 & 0,000 & Berpengaruh Signifikan \\
Customer Value (X2) & 2,614 & 1,988 & 0,000 & Berpengaruh Signifikan \\
Trust (X3) & 2,472 & 1,988 & 0,000 & Berpengaruh Signifikan \\
\hline
\end{tabular}

Tabel 4. Menunjukkan hasil uji hipotesis atau uji t, yang menggunakan tingkat kepercayaan $95 \%$, sehingga nilai $\alpha=0,05$ dan $\mathrm{t}$ tabel 1,988. Dari hasil analisis tersebut dapat dijelaskan bahwa, variabel relationship marketing memperoleh nilai t hitung $>\mathrm{t}$ tabel yaitu $3,904>1,988$ dengan taraf signifikan yaitu $0,000<0,05$ yang berarti Ho ditolak dan Ha diterima. Berdasarkan perhitungan diatas membuktikan bahwa relationship marketing secara parsial berpengaruh signifikan terhadap loyalitas pelanggan. Dengan demikian dapat dikatakan bahwa $\mathrm{H} 1$ diterima. 
Hal ini berarti semakin baik relationship marketing yang dapatkan oleh pelanggan, maka semakin meningkat juga pengaruhnya terhadap loyalitas pelanggan pada PT. Asuransi Jiwasraya cabang Kota Malang. Hasil ini juga mendukung penelitian terdahulu yaitu Pasaribu (2017) menyatakan bahwa hubungan pemasar membuat pengaruh positif dan signifikan terhadap loyalitas pelanggan dan juga Syaiful (2015) yang menyatakan bahwa relationship marketing memiliki pengaruh positif dan signifikan terhadap loyalitas pelanggan.

Variabel customer value memperoleh nilai $\mathrm{t}$ hitung $>\mathrm{t}$ tabel yaitu 2,614>1,988 dengan taraf signifikan yaitu $0,010<0,05$ yang berarti Ho ditolak dan Ha diterima. Berdasarkan perhitungan diatas membuktikan bahwa customer value secara parsial berpengaruh signifikan terhadap loyalitas pelanggan. Dengan demikian dapat dikatakan bahwa $\mathrm{H} 2$ diterima.

Hal ini menunjukkan semakin tinggi tingkat customer value yang didapatkan oleh pelanggan, maka semakin tinggi juga pengaruhnya terhadap loyalitas pelanggan pada PT. Asuransi Jiwasraya cabang kota Malang. Hasil penelitian ini juga mendukung penelitian terdahulu yaitu oleh Rahi (2016) yang menyatakan bahwa customer value $\begin{array}{lc}\text { memiliki } & \text { pengaruh positif dan } \\ \text { signifikan } & \text { terhadap loyalitas }\end{array}$ pelanggan.

Variabel trust memperoleh nilai t hitung > t tabel yaitu 2,472 dengan taraf signifikan yaitu $0,015<0,05$ yang berarti $\mathrm{Ho}$ ditolak dan $\mathrm{Ha}$ di terima. Berdasarkan perhitungan diatas membuktikan bahwa trust secara parsial berpengaruh positif dan signifikan terhadap loyalitas pelanggan. Dengan demikian dapat dikatakan bahwa $\mathrm{H} 3$ diterima.

Melalui hasil perhitungan yang telah dilakukan pada uji $\mathrm{t}$ membuktikan bahwa trust secara parsial berpengaruh positif dan signifikan terhadap loyalitas pelanggan pada PT. Asuransi Jiwasraya cabang kota Malang. Hal ini menunjukkan semakin tinggi kepercayaan atau trust yang dirasakan oleh pelanggan, maka semakin tinggi juga pengaruhnya terhadap loyalitas pelanggan pada PT. Asuransi Jiwasraya cabang kota Malang.

Hasil penelitian ini juga mendukung penelitian terdahulu yaitu Fihartini (2010), yang menyatakan bahwa kepercayaan berpengaruh positif dan signifikan terhadap loyalitas pelanggan. Kepercayaan merupakan faktor yang membangun loyalitas pelanggan asuransi untuk tetap bertahan pada suatau perusahaan asuransi.

Tabel 5. Hasil Uji F

\begin{tabular}{cccc}
\hline Model & F hitung & F tabel & Signifikansi \\
\hline 1 & 62,280 & 2,70 & 0,000 \\
\hline
\end{tabular}


Tabel 5. menunjukkan hasil uji F. Uji F dilakukan untuk mengetahui tingkat pengaruh variabel bebas secara simultan terhadap variabel terikat atau goodness of fit model penelitian ini. Hasil tersebut menunjukkan bahwa nilai $\mathrm{F}$ hitung
$62,280>\mathrm{F}$ tabel 2,70 atau nilai signifikan sebesar $0,000<0,05$ yang artinya relationship marketing $(X 1)$, customer value (X2), dan trust (X3) secara simultan berpengaruh signifikan terhadap loyalitas pelanggan

Tabel 6. Hasil Uji Pengaruh Dominan

\begin{tabular}{lc}
\hline \multicolumn{1}{c}{ Variabel } & $\begin{array}{c}\text { Standardized } \\
\text { Coeficient Beta }\end{array}$ \\
\hline Relationship Marketing (X1) & 0,402 \\
Customer Value (X2) & 0,282 \\
Trust (X3) & 0,209
\end{tabular}

Tabel 6. menunjukkan hasil uji pengaruh dominan pada tingkat kepercayaan $95 \%$ atau taraf signifikan adalah 5\% dengan kriteria penilaiannya, dimisalkan nilai koefisien Beta X1 dan X2 $\leq$ nilai koefisien Beta X3. Tabel 6 . menunjukkan bahwa nilai koefisein beta variabel relationship marketing adalah yang terbesar dibandingkan dengan customer value dan trust. Hal tersebut menunjukkan variabel relationship marketing memiliki kontribusi pengaruh yang paling besar terhadap variabel loyalitas pelanggan.

\section{SIMPULAN}

Berdasarkan hasil penelitian dan pembahasan yang telah dilakukan dapat disimpulkan bahwa semakin baik hubungan pemasar dengan pelanggan atau nasabah, maka semakin baik tingkat loyalitas terhadap perusahaan PT. Asuransi Jiwasraya cabang kota Malang. Semakin baik nilai atau manfaat yang diperoleh dari pengorbanan yang diharapkan dan didapatkan, maka semakin baik tingkat loyalitas pelanggan terhadap PT. Asuransi Jiwasraya cabang kota Malang.
Semakin tinggi tingkat kepercayaan pelanggan terhadap perusahaan maka, semakin baik tingkat loyalitas pelanggan terhadap perusahaan PT. Asuransi Jiwasraya cabang kota Malang. Dan relationship marketing menjadi variabel yang memiliki kontribusi terbesar terhadap loyalitas pelanggan PT. Asuransi Jiwasraya cabang kota Malang, hal tersebut menunjukkan bahwa pelanggan akan menjadi loyal ketika hubungan pemasar dengan pelanggan terjalin dengan baik.

PT. Asuransi Jiwasraya cabang kota Malang peneliti sarankan untuk mempertahankan atau meningkatkan relationship dari segi ikatan (bonding), empati (empathy), dan timbal balik (reciprorty). Hubungan kerjasama yang baik dengan pelanggan, menjaga komunikasi dengan pelanggan, dan memberikan kemudahan dalam pelayanan terhadap pelanggan. Sehingga pelanggan akan semakin loyal terhadap perusahaan. Untuk meningkatkan loyalitas pelanggan PT. Asuransi Jiwasraya cabang kota Malang juga disarankan untuk memperhatikan aspek manfaat atau nilai yang diperoleh oleh pelanggan 
dan timbal balik bagi profabilitas perusahaan.

\section{DAFTAR PUSTAKA}

Barnes, J.G. 2011. Secrets of Customer Relationship

Management (Rahasia

Manajemen

Hubungan

Pelanggan).

Edisi

II.

Yogyakarta: Andi Offset.

Cannon, J. P., Perreault Jr, W. D., \& McCarthy, E. J. 2008. Pemasaran Dasar (Pendekatan Manajerial Global). Salemba Empat. Jakarta

Ferrinadewi, Erna. 2008. Merek \& implikasi pada strategi Pemasaran, edisi pertama. Yogyakarata: Graha Ilmu.

Fihartini, Yuniarti. 2010. "Pengaruh Kepercayaan dan Kualitas Layanan Terhadap Loyalitas Pelanggan".

Google.scholar.com. Universitas Lampung.

Griffin, Jill. 2010. Customer Loyalty: Menumbuhkan dan Mempertahankan Kesetiaan Pelanggan. Edisi Revisi dan Terbaru. Jakarta: Erlangga.

Kotler, Philip. 2002. Manajemen Pemasaran. Jilid 1. Edisi melenium. Jakarta. Prehallindo 2005. Manajemen Pemasaran, Edisi 11, PT Indeks Kelompok Gramedia, Jakarta. \& G. Amstrong. 2010. Prinsip - Prinsip Pemasaran. Edisi 12. Terjemahan oleh Bob Sabran, M.M. Jilid 1. Jakarta: PT Gelor Aksara Pratama.

Pasaribu, Verawati. 2017. "Pengsaruh Customer
Relationship Marketing dan Brand Trust terhadap Custumer Lolalty pada PT. Asuransi Jiwasraya (Persero) Cabang Pekanbaru". JOM FISIP Vol. 4 No. 2 - Oktober 2017. Universitas Riau.

Rahi, Samar. 2016. "Impact of Customer Value, Public Relations Perception and Brand Image on Customer Loyalty in Services Sector of Pakistan". Arabian J Bus Manag. Review S2: 004. doi: 10.4172/22235833.S2-004. Universitas Sultan Zainal Abidin.

Ramadania. 2002. "Kepercayaan dan Komitmen Sebagai Perantara Kunci Relationship Marketing Dalam Membangun Loyalitas". Jurnal Riset Ekonomi dan Manajemen. Vol.2 No.1, Hal. 33-52.kotler

Syaiful. Mochamad. 2015. “ Pengaruh Relationship Marketing, Komitmen, dan Kepercayaan terhadap Loyalitas Pelanggan AUTO 2000 Sungkono". Jurnal Ilmu dan Riset Manajemen, Vol. 4, No. 12, hlm: 2-16

Tandjung, Widodo. 2004. Marketing Management Pendekatan Pada Nilai-nilai Pelanggan. Malang: Banyumedia Publishing.

Tjiptono, Fandy. 2014. Pemasaran Jasa-Prinsip, Penerapan, dan Penelitian. Yogyakarta: ANDI.

Vanessa, Gaffar. 2007. Customer Relationship Management and Marketing Public Relations. Bandung: Alfabeta. 